\title{
Genetic Modification of Rosa Pinna (Clerodendrum philippinum Schauer) with gai Mutant Gene for Improved Plant Architecture
}

\author{
E.D.U.D. De Silva, M.N.K. Herath, P.A.G.S.K. Perera, K.K.S. Fernando ${ }^{1}$ and S.E. Peiris ${ }^{2 *}$
}

\author{
Postgraduate Institute of Agriculture \\ University of Peradeniya \\ Sri Lanka.
}

\begin{abstract}
Rosa pinna (Clerodendrum philippinum Schauer), is a shrub with attractive and fragrant flowers. However, the tall and spread architecture and high leaf to flower ratio hinder its use as an ornamental plant. Hence, changing the level of acceptance of $\underline{C}$. philippinum by incorporating a dwarfing gene to the plant is considered useful. A study was conducted to find a suitable regeneration medium and ultimately to modify the plant architecture through transformation of the gibberellic acid inhibitor (gai) mutant dwarfing gene by particle bombardment. Effects of different concentrations of thidiazuron (TDZ:Nphenyl N' 1,2,3-thidiazol-5-yl urea) on callus initiation and regeneration of shoots and the effects of microcareer flying distance in gene transformation of $\underline{C}$. philippinum were investigated. The regenerated shoots were first cultured on hormone free MS medium and transferred to a MS medium with $0.5 \mathrm{mg} / \mathrm{L}$ indole butyric acid for rooting after four weeks. The shortest duration for callus initiation, the largest callus volume (28 days after establishment) and the highest number of shoots (75 days after establishment) were observed in $1.5 \mathrm{mg} / \mathrm{L} \mathrm{TDZ}$ in the MS medium. Results of transferring the gai mutant gene to in vitro leaves of $\underline{C}$. philippinum revealed that both the shortest time duration and the highest plant regeneration were at $9 \mathrm{~cm}$ micro-carrier flying distance. Leaf tissues of regenerated plants, which carry the gai mutant gene, positively responded for the beta-glucuronidase (GUS) assay. The regenerated shoots were rooted and successfully acclimatized.
\end{abstract}

Keywords: Clerodendrum philippinum, gai mutant gene, GUS, particle bombardment, thidiazuron

\section{INTRODUCTION}

Floriculture has been identified as one of the most profitable agro-enterprises, which could generate increased income and self-employment from unit land area. Development of floriculture sector will help to earn foreign exchange and it will create job opportunities in the country. The floriculture sector is rapidly changing and requires the regular input of new varieties. Therefore, introduction of new developed plant varieties is essential in order to achieve success and sustainability of the industry.

The climatic variation coupled with diverse terrain enables Sri Lanka to develop a wide range of floricultural plants ranging from tropical to temperate, supply of which is free from seasonal interruptions (Samarasekara, 1995). There are plenty of plants species exhibiting

\footnotetext{
Agricultural Biotechnology Centre, University of Peradeniya, Sri Lanka

Department of Crop Science, Faculty of Agriculture, University of Peradeniya, Sri Lanka

Corresponding author: sriyanip@pdn.ac.lk
} 
ornamental characteristics however, little attention has been given to those commercially. Therefore, there is a high potential and possibility to develop and popularize these plant varieties as commercialized ornamental plants.

Rosa pinna (Clerodendrum philippinum Schauer.) is a perennial woody sub shrub belongs to the family Lamiaceae. It grows to the height of 0.6-1.5 m. Leaves are broad, up to $20-25 \mathrm{~cm}$ long and nearly as wide, margins toothed, somewhat lobed. Flowers are seen in tight clusters, white with pink or red tinge and highly fragrant at sundown. Each flower is like a tiny rose or rosebud, the calyx which is pink/purple is beautiful and prominent before the corolla opens. Origin of this plant is China/Japan and it is already distributed in South Asia including Sri Lanka (Moldenke \& Moldenke, 1981). Due to its remarkable floral qualities, it can be introduced as a popular potted plant. However, its plant architecture has to be improved to the level of acceptance as a flowering pot plant which should have a higher flower to leaf ratio. Hence, plant architecture of this plant species needs to be modified. This can be done by incorporating a dwarfing gene.

Most methods of plant transformation applied to genetically modified crops require that the whole plant is regenerated from isolated plant cells or tissues that have been genetically transformed. Regeneration is carried out in vitro so that the environment and growth medium can be manipulated to ensure a high frequency of regeneration (Taylor \& Fauquet, 2002; Mauro, 1995). The subsequent regeneration step is often the most difficult in plant transformation studies. Thus key to success in integrating plant tissue culture into plant transformation strategies due to the realization that a quick and efficient regeneration system must be developed. This study was conducted with the objectives of developing a successful in vitro protocol to regenerate $C$. philippinum from leaves which are exposed to transferring of gai mutant gene to select the most successful gene transfer with different microcareer flying distances.

\section{MATERIALS AND METHODS}

Experiments were conducted in the Tissue Culture Laboratory, Department of Crop Science, Faculty of Agriculture, University of Peradeniya. Gene transferring was performed at the Biotechnology Centre, Faculty of Agriculture, University of Peradeniya.

\section{Effects of different TDZ concentrations on callus induction and regeneration}

Leaf segments $\left(1 \mathrm{~cm}^{2}\right)$ of $C$. philippinum from already established in vitro shoots were taken using a sharp scalper and a pair of scissors and established on full MS (Murashige \& Skoog, 1962) solid medium with $3 \%$ sucrose, $100 \mathrm{mg} / \mathrm{L}$ myo inositol and TDZ concentrations of 0 , $0.5,1.0,1.5 \mathrm{mg} / \mathrm{L}$ as well as $1 / 2 \mathrm{MS}$ medium with the same composition and TDZ concentrations for callus induction. Each culture tube consisted of $10 \mathrm{~mL}$ of the medium. The experimental set up was arranged in a Completely Randomized Design (CRD) with two replicates. Each treatment consisted of ten in vitro cultured leaf segments. These cultures were incubated at $25^{\circ} \mathrm{C}$ under the cool florescent light with intensity of 1500 lux. The number of days taken for callus initiation, callus volume $\left(\mathrm{cm}^{3}\right)$ and number of shoots/explant were recorded. Regenerated shoots were further multiplied and rooted in the full MS medium without supplementing any growth regulator. ANOVA procedure was followed by using statistical analytical system (SAS, 1990) for the factorial analysis. The significant difference between means was estimated at 5\% level using Duncan's Multiple Range Test. 


\section{Effects of microcareer flying distance on regeneration of $C$. philippinum}

\section{Preparation of medium for experiment}

Leaf parts of $1 \mathrm{~cm}^{2}$ were taken from in vitro $C$. philippinum plants which were grown in hormone-free medium as to reduce the hormonal effects. Twenty randomly selected leaf explants of $1 \mathrm{~cm}^{2}$ in uniform size were used in each treatment. Full strength MS medium, with $3 \%$ sugar and $100 \mathrm{mg} / \mathrm{L}$ myo inositol was used throughout the experiment. Growth regulators were added to the medium depending on the experiment. After volumerising the medium, $\mathrm{pH}$ was adjusted to 5.8 . Then phytagel, the solidifying agent $(0.46 \% \mathrm{w} / \mathrm{v})$, was added and boiled in the microwave oven. Then the medium was poured into Petri-dishes (to be used in gene transformation) and culture jars (to be used after the gene transformation) and sterilized in an autoclave for 20 minutes under $1.05 \mathrm{~kg} / \mathrm{m}^{2}$ pressures and temperature at $121^{\circ} \mathrm{C}$.

\section{Preparation of leaf explants for the bombardment}

Fully expanded leaves from the in vitro grown $C$. philippinum were used as the primary explants. In order to pre-condition the target leaf tissues, those were cut into approximately 1 $\mathrm{cm}^{2}$ sections and cultured, with their abaxial side touching the medium, on MS medium supplemented with $100 \mathrm{mg} / \mathrm{L}$ myo-inositol, $6 \%$ sugar and $0.25 \mathrm{M}$ mannitol in Petri-dishes, 2 days prior to gene transformation. They were incubated at $23-25{ }^{\circ} \mathrm{C}$ temperature under $16 / 8$ $\mathrm{h}$ (day/night) with a light intensity of 1500 lux.

\section{Gene transformation}

For particle bombardment, the plasmid pJIT 60 construct expressing gai under the control of the $35 \mathrm{~S}$ CaMV promoter and containing ampicillin resistance and GUS genes as a selector and a marker, respectively was used. Plasmid DNA was absorbed on gold microcarriers (0.6 $\mu \mathrm{m}$ in diameter, Bio-Rad) as described by Bio-Rad. Fifty $\mu \mathrm{L}$ aliquots containing $3.0 \mathrm{mg}$ of gold particles prewashed in ethanol were mixed with $2 \mu \mathrm{L}$ of DNA $(1 \mu \mathrm{g} / \mu \mathrm{L}), 50 \mu 1 \mathrm{CaCl}_{2}$ $(2.5 \mathrm{M}), 20 \mu \mathrm{L}$ spermidine $(0.1 \mathrm{M})$ and $21 \mu \mathrm{L}$ of deionized water in 1.5 microcentrifuge tube by vortexing. The resulting suspension was spinned down at $6000 \mathrm{rpm}$ for 1 minute and the supernatant was discarded. Particles were resuspended in $250 \mu \mathrm{L}$ of $95 \%$ ethanol and vortexed well until clumps disappeared. Then those were spinned down at $13000 \mathrm{rpm}$ for 20 seconds and the supernatant was removed. Finally, it was resuspended in $50 \mu \mathrm{L}$ of $95 \%$ ethanol.

\section{Gene transformation using particle bombardment}

In order to achieve aseptic conditions prior to bombardment, the rupture disk retaining cap, stopping screens, macrocarrier holder with macrocarriers were sterilized by autoclaving. Rupture disks were surface sterilized by briefly dipping in $70 \%$ isopropanol for few seconds and microcarrier launch assembly, chamber walls and target shelf were sterilized by wiping with $70 \%$ ethanol.

Twenty leaf explants maintained on pre-conditioning medium were arranged in a circle of about $3 \mathrm{~cm}$ diameters in the centre of agar Petri-dishes. Bombardment was carried out with a Biolistic PDS-1000/He particle delivery system (Bio-Rad). All bombardments were 
performed at a pressure of $1550 \mathrm{psi}$, a vacuum of $27 \mathrm{Hg}$ inch with three microcarrier flight distances $(3,6,9 \mathrm{~cm})$

\section{Regeneration from gene transferred leaf explants}

Control treatment and gene transferred leaf explants were separately transferred on to the MS medium supplemented with $0.5 \mathrm{mg} / \mathrm{L}$ ampicilin and $1.5 \mathrm{mg} / \mathrm{L}$ TDZ for regeneration in glass jars. All cultures were maintained at $23-25^{\circ} \mathrm{C}$ temperature under $16 / 8 \mathrm{~h}$ (day/night) photoperiod with a light intensity of approximately 1500 lux throughout the experiment. Jars were arranged according to complete randomized design. All the cultures were transferred to fresh medium at 30 days interval. Number of days taken for regeneration and the number of shoots produced per explant after 75 days from the gene transferring were recorded. Regenerated shoots were cultured on hormone free MS medium for 4 weeks then transferred to MS medium supplemented with $0.5 \mathrm{mg} / \mathrm{L}$ Indole butyric acid (IBA) for rooting.

\section{GUS assay}

Leaf samples were collected from several independent transformed plants and tested for GUS activity. Leaf samples were cleaned and separately placed in $10 \mathrm{~mL}$ test tubes containing the GUS assay solution. They were placed in a water bath at $37^{\circ} \mathrm{C}$ temperature for 30-45 minutes (Karcher, 2002).

All the experiments were arranged in a completely randomized design. Number of days taken to initiate the regeneration and number of shoots produced 75 days after gene transformation were analyzed using one way ANOVA with MINITAB statistical software.

\section{RESULTS AND DISCUSSION}

\section{Effects of different concentrations of TDZ on callus induction and shoot regeneration on in vitro leaves of $C$. philippinum}

Results revealed that the callus on leaf explants appeared within nine days from culture establishment on full MS medium with $1.5 \mathrm{mg} / \mathrm{L} \mathrm{TDZ}$ and this is the shortest time period when compared with other treatments. Obviously the longest time duration for callus induction was taken by both the full and half MS medium without TDZ or rather without any growth regulators. Number of days taken for callus initiation was significantly decreased with the concentration of TDZ from 0 to $1.5 \mathrm{mg} / \mathrm{L}$ in both MS levels as illustrated in Fig.1. 


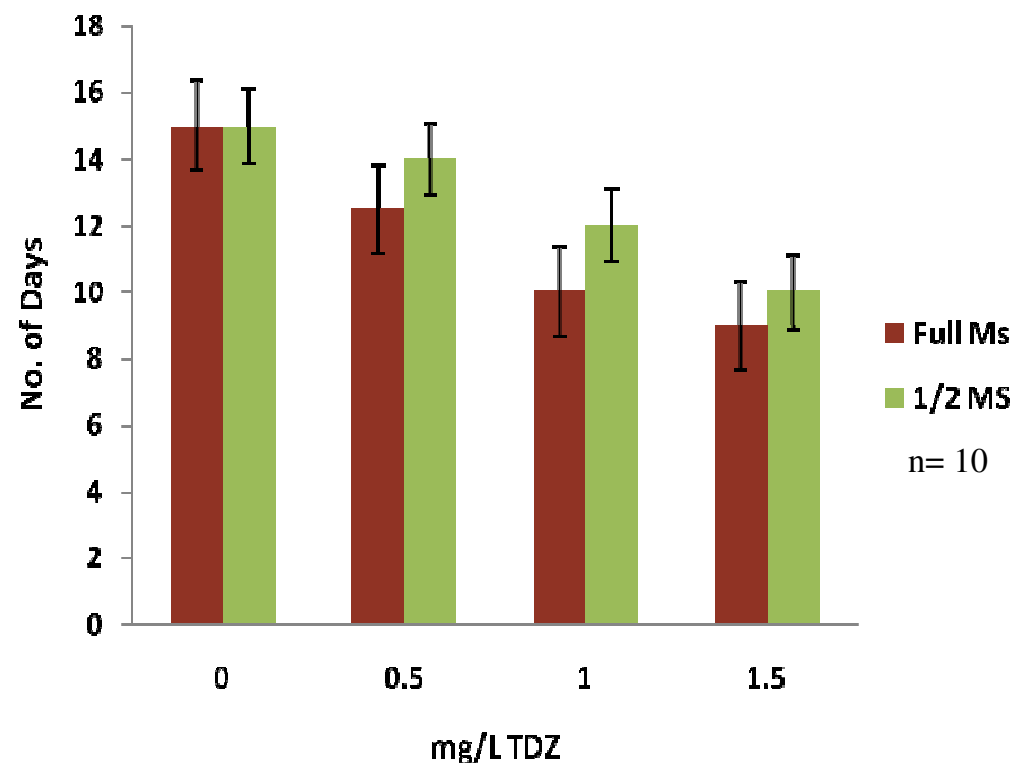

Fig 1. Effect of different concentrations of TDZ on callus initiation of $C$. philippinum.

Callus formation at the basal cut ends of nodal explants has been reported in Gymnema sylvestre (Komalavalli \& Roa, 2000) and Holostemma adakodiens chult with TDZ (Martin, 2003). It may be due to the action of accumulated auxin at the basal cut ends which stimulate cell proliferation especially in the presence of cytokinin like activity in TDZ. Similarly higher callus formation could be observed in cut ends of in vitro leaf pieces of $C$. philippinum. Thomas (2003) stated that TDZ at low concentrations $(0.001$ to $0.1 \mathrm{mg} / \mathrm{L})$ was better in inducing callus and producing plantlets with shoot and root growth.

\section{Amount of Callus produced}

Significantly higher callus volume was observed on full MS with $1.5 \mathrm{mg} / \mathrm{L}$ TDZ while the lowest callus volume was recorded on both full and half MS medium without TDZ (Table 1). According to the results, callus volume increased with the concentration of TDZ.

A definite level of a hormone or different hormones is required for proliferation of callus (Yasmin et al., 2003). Thidiazuron is a hormone having the effect of both cytokinin and auxin (Victor et al., 1991). This finding supports significantly higher callus volume (3.8 $\mathrm{cm}^{3}$ ) observed in full MS supplemented with $1.5 \mathrm{mg} / \mathrm{L}$ TDZ. However, the explants cultured on MS medium without growth regulators produced less amount of callus $\left(0.1 \mathrm{~cm}^{3}\right)$. This result is in keeping with results obtained by Fiegert et al. (2000) and Jayasree et al. (2001).

Significantly higher mean number of shoots per explant (9.6) was recorded by full MS medium supplemented with $1.5 \mathrm{mg} / \mathrm{L}$ TDZ. All explants in TDZ concentrations (except without TDZ) produced significantly higher amount of shoots ranging from 5 to 9.6 . This shows that full MS medium supported shoot regeneration than the half MS medium with TDZ. Explants on medium without any hormones produced only callus (Fig. $2 \& 3$ ). 
Table 1. Effect of different concentrations of TDZ on callus induction of in vitro leaf of C. philippinum.

\begin{tabular}{lcc}
\hline TDZ concentration & \multicolumn{2}{c}{ Callus Volume $\left(\mathbf{c m}^{3}\right)$} \\
\hline $\mathbf{m g} / \mathrm{L}$ & Full MS & Half MS \\
\hline 0 (control) & $0.1^{\mathrm{c}}$ & $0.09^{\mathrm{c}}$ \\
$0.5 \mathrm{mg} / \mathrm{L}$ & $1.5^{\mathrm{b}}$ & $1.20^{\mathrm{b}}$ \\
$1.0 \mathrm{mg} / \mathrm{L}$ & $1.7^{\mathrm{b}}$ & $1.52^{\mathrm{b}}$ \\
$1.5 \mathrm{mg} / \mathrm{L}$ & $3.8^{\mathrm{a}}$ & $2.05^{\mathrm{b}}$ \\
\hline
\end{tabular}

Values with the same letters are not significantly different among treatments based on Duncan New Multiple Range Test at $\mathrm{P}<0.05 . \mathrm{n}=10$

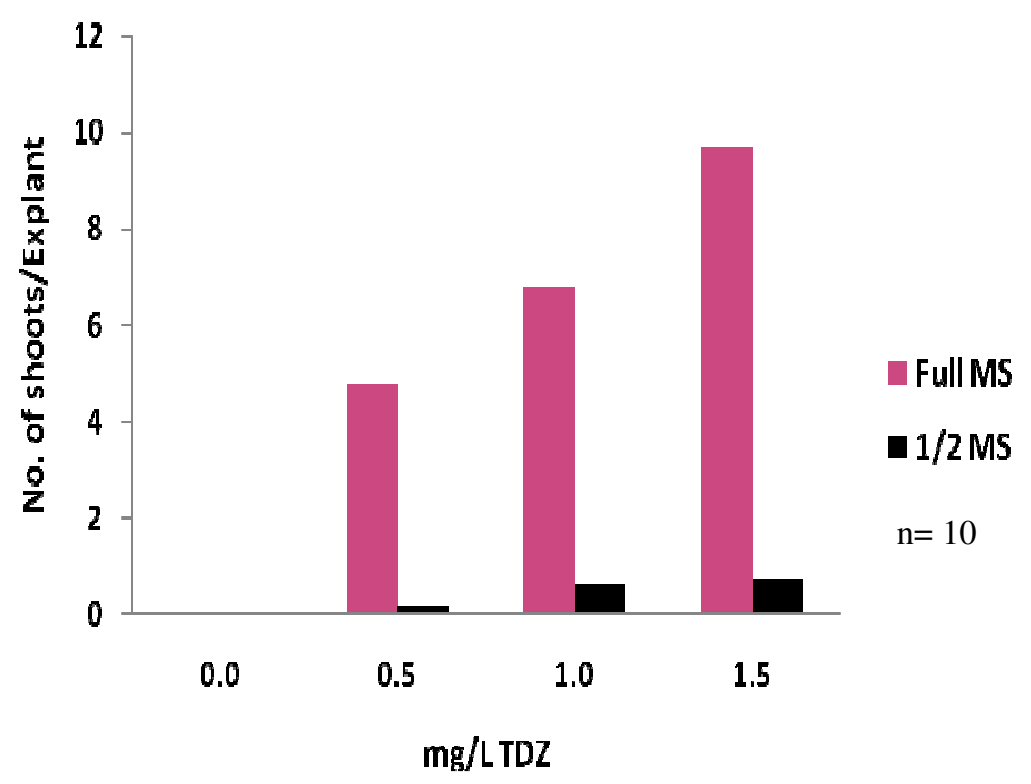

Fig 2. Effect of different concentrations of TDZ on shoot induction in in vitro leaf of $C$. philippinum.

The growth regulator TDZ induces physiological responses such as regulation of cell division, growth and differentiation of tissues and organs and chlorophyll biosynthesis (Victor et al., 1991). The callus and progressive shoot production obtained in this study is as a result of the behaviour of the TDZ. Elaleem et al. (2009); Huetteman \& Preece (1993) and Murthy et al. (1995) have revealed that TDZ, a synthetic phenylurea, is considered to be one of the most active cytokinins for shoot induction in plant tissue culture. 


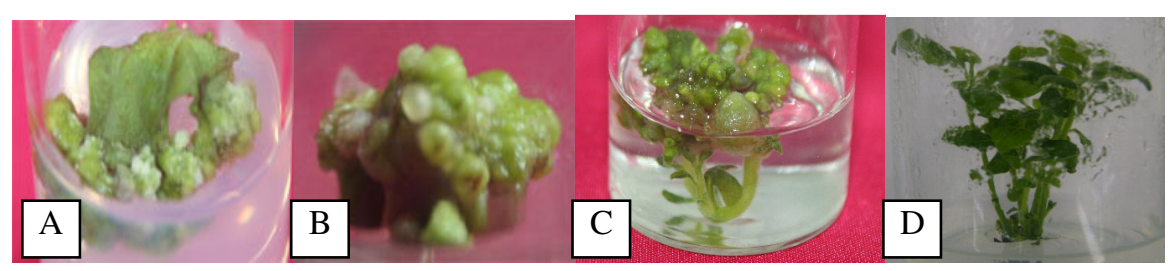

Fig 3. A \& B: Proliferation of callus on full MS medium containing $1.5 \mathrm{mg} / \mathrm{L} \mathrm{of} \mathrm{TDZ,}$ $\mathrm{C}$ : shoot regeneration on the medium (MS + TDZ $1.5 \mathrm{mg} / \mathrm{L}) \mathrm{D}$ : regenerated plant after gene transformation

Thidiazuron (TDZ), a urea-derived cytokinin, is a potential cytokinin for woody plant tissue culture (Huetteman \& Preece, 1993) and is extensively used for the induction of shoots in several plant species (Li et al., 2000; Mohan \& Krishnamurthy, 2002; Liu et al., 2003). The present study also reveals an efficient regeneration system for C. philippinum using thidiazuron.

When regenerated cultures were transferred into MS medium without supplementing any growth regulators, they further multiplied and rooting was also stimulated. Roots were produced subsequently after removal of the effect of cytokinin in the absence of TDZ. Roots were elongated and more roots were produced when transferred to MS medium containing $0.5 \mathrm{mg} / \mathrm{L} \mathrm{IBA}$.

\section{Effects of different microcarrier flight distances for regeneration}

Number of shoots produced after 75 days from the bombardment varied from 12.1 to 17.4 in the gene transferred treatments and there was no significant difference $(p>0.05)$ among them. However, the mean average number of shoots after 75 days of control treatment was 0.1 and was significantly different from the explants which received the gene transfer treatments $(\mathrm{p}<0.05)$.

Table 2. Effect of different microcarrier flight distances on number of shoots 75 days after gene transformation.

\begin{tabular}{lcc}
\hline $\begin{array}{c}\text { Treatment } \\
\text { No }\end{array}$ & $\begin{array}{c}\text { Microcareer } \\
\text { flight distance }(\mathbf{c m})\end{array}$ & $\begin{array}{c}\text { Avg. No of } \\
\text { shoots }\end{array}$ \\
\hline 1 & Control & 0.1 \\
2 & $3 \mathrm{~cm}$ & 13.1 \\
3 & $6 \mathrm{~cm}$ & 12.1 \\
4 & $9 \mathrm{~cm}$ & 17.4 \\
\hline
\end{tabular}

The average number of days taken for regeneration of shoots varied from 59.4 to 80.2 among the treatments. The shortest time taken for regeneration was 59.4 days for the $9 \mathrm{~cm}$ microcareer flying distance and the longest time taken for regeneration was 80.2 days which was for the control treatment (without exposing to gene bombardment) which is significantly different from the gene transferred treatments $(\mathrm{p}<0.05)$. 
Table 3. Effect of different microcarrier flying distances on time taken for regeneration.

\begin{tabular}{ccc}
\hline Treatment No & $\begin{array}{c}\text { Microcareer } \\
\text { flying distance }(\mathbf{c m})\end{array}$ & $\begin{array}{c}\text { Avg. No of days to } \\
\text { produce shoot }\end{array}$ \\
\hline 1 & Control & 80.2 \\
2 & $3 \mathrm{~cm}$ & 69 \\
3 & $6 \mathrm{~cm}$ & 66.7 \\
4 & $9 \mathrm{~cm}$ & 59.4 \\
\hline
\end{tabular}

When the control and transformed tissues were tested for GUS activity, results showed that GUS gene was active in some transformed tissues as indicated by the presence of blue colour (Fig. 4). The control leaf died due to toxicity of gulcourinidase chemicals.

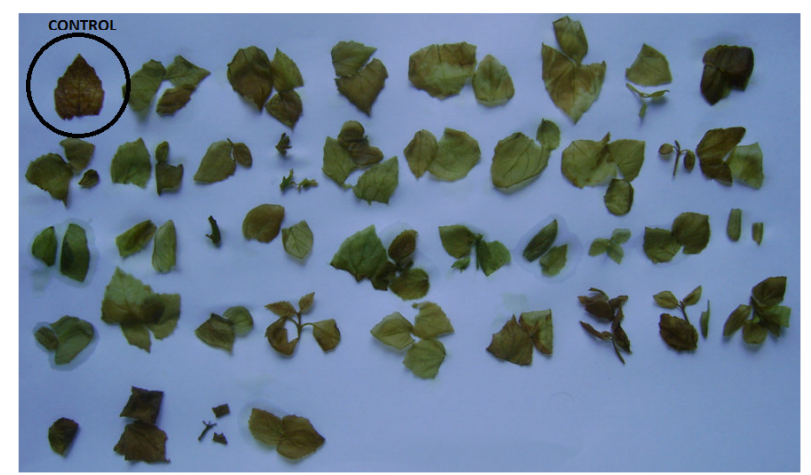

Fig. 4. Tissues tested with GUS assay.

Microcarrier flight distance is a very important parameter which determines microcarrier penetration and transformation. In the present experiment, distance between stopping screen and target shelf (microcarrier flight distance) was adjusted and the optimal distances for the efficient transformation was evaluated. The longer the distance (among the three compared) the larger the cover area which is effective on penetration of microcareers into the tissues and reduces harm on cells in the effect of the gas shock wave on macrocarrier acceleration.

According to the research conducted by Gaunt et al. (1999) using wheat tissues, low acceleration pressure (650-1100 psi) had given better results than at high pressure (1300$1550 \mathrm{psi}$ ). Since a large area was covered by the low acceleration pressure, an even distribution of microparticles had also been achieved. High expression is due to low bombardment shock and tissue damage. At low distance, only a small area is targeted and they are stimulated to severe tissue damages by dividing cells.

The smaller the distance, more powerful the effect of the gas shock wave on macrocarrier acceleration. Therefore, it can lead to high tissue damage. However, those distances depend on the properties of the targeted plant tissues such as thickness of the leaf blade etc. In the present study, regeneration was not significantly different among the treatments and the most suitable micro-carrier flying distance can be recommended as $9 \mathrm{~cm}$ with reference to effectiveness of gene transfer in C. philippinum. There was not much tissue damage in the control treatment other than the margins in the explants preparation. Therefore, there is a low 
stimulation to cell division than the regeneration. When explants were transferred to regeneration medium ampicilin, the antibiotic in the medium had reduced cell division, which may also have prevented regeneration. When it is degraded with time, tissues can begin regeneration. Therefore, regeneration of the control could have occurred later. However in gene transferred tissues, there is an ampicilin resistant gene which can avoid the above influence. With respect to the microcarrier flight distance, it is obvious that the high regeneration rate has been achieved at $9 \mathrm{~cm}$ distance.

Histochemical localization of B-Glucuronidase (GUS): Histochemical localization of GUS activity was performed using GUS substrate 5-bromo-4-chloro-3- indolylglucuronide (xGluc). Tissues from gene transferred plants consisted of the gene which produces $\beta$ Glucuronidase (GUS), gusA gene will respond by producing the enzyme beta glucuronidase (GUS). When plant tissue is incubated with the chromogenic substrate Xgluc, those tissues that produce GUS turn blue. This can be used as a marker for gene transformation. The GUS assay is easy to perform, sensitive, relatively inexpensive, highly reliable, safe, requires no specialized equipment, and is highly visual (Jefferson et al.,1987).

\section{CONCLUSIONS}

Callus initiation and regeneration of shoots are significantly higher in full MS medium supplemented with $1.5 \mathrm{mg} / \mathrm{L} \mathrm{TDZ}$ for in vitro leaves of Clerodendrum philippinum. Regenerated shoots were successfully rooted on MS medium with $0.5 \mathrm{mg} / \mathrm{L}$ Indole butyric acid and acclimatized. Despite the fact that regeneration was not significantly different among three different microcareer flying distances, the most suitable micro-carrier flying distance can be recommended as $9 \mathrm{~cm}$ with reference to effectiveness of gene transfer in Clerodendrum philippinum. GUS assay confirmed the transfer of the gene.

\section{ACKNOWLEDGEMENT}

Financial assistance from CARP (CARP 12/635/477) for this study is greatly appreciated.

\section{REFERENCES}

Elaleem, K.G.A, Modawi, R.S. and Khalafalla, M.M. (2009). Effect of plant growth regulators on callus induction and plant regeneration in tuber segment culture of potato cultivar 'diamante'. African Journal of Biotecnology. 8(11), 2529-2534.

Fiegert, A.K., Mix, W.G. and Vorlop, K.D. (2000). Regeneration of Solanum tuberosum L. Tomensacv, induction of somatic embryogenesis inliquid culture for the production of artificial seed. LandbauforschungVolkenrode, 50, 199-202.

Gaunt, S.R., Riley, A., Barcelo, P. and Lazzeri, P.A. (1999). Analysis of particle bombardment parameters to optimise DNA delivery into wheat tissues. Plant Cell Rep. 19, 118-127.

Huetteman, C.A. and Preece, J.E. (1993). Thidiazuron: Apotent cytokinin for woody plant tissue culture. Plant Cell Tiss. Org. Cult. 33, 105-119. 
Jayasree, T., Pavan, U., Ramesh, M., Rao A.V., Reddy, K.J.M. and Sadanandam, A. (2001). Somatic Embryogenesis from leaf culture of potato.Plant Cell Tiss. Org. Cult. 64, 13-17.

Jefferson, R. A., Kavanagh, T. A. and Bevan, M.W. (1987). GUS fusions: $\beta$-glucuronidase as a sensitive and versatile gene fusion marker in higher plants. EMBO Journal. 6, 3901-3907.

Karcher, S. J. (2002). Blue plants: Transgenic plants with the GUS reporter gene. Pages 2942.In: Tested studies for laboratory teaching, Volume 23 (M. A. O'Donnell, Editor). Proceedings of the 23rd Workshop/Conference of the Association for Biology Laboratory Education (ABLE), 392.

Komalawali, N. and Rao, M.V. (2000). In vitro micropropagation of Gymnema sylvestre: a multipurpose medicinal plant. Plant Cell Tiss. Org. Cult. 105, 61-97.

Li, H., Murch, S.J. and Saxena P.K. (2000). Thidiazuron Induced de Novo Shoot Organogenesis on Seedlings, Etiolated Hypocotyls and Stem Segments of Huang-qin. Plant Cell Tiss. Org. Cult. 62, 169-173.

Liu, C.Z., Murch, S. J., Demerdash, M. E. L. and Saxena, P. K. (2003).Regeneration of the Egyptian medicinal plant Artemisia judaica L. Plant Cell Rep. 21, 525D-530.

Martin, K.P. (2003). Plant regeneration through somatic embryogenesis on Holostemma adakodien, a rare medicinal plant. Plant Cell Tiss. Org. Cult. 72, 79-82.

Mauro, M. C., Toutain, S., Walter, B., Pinck, L. Otten L., Coutous-Thevenot, P., Deloire, A. and Barbier, P.(1995). High efficiency regeneration of grapevine plants transformed with the GFLV coat protein gene. Plant Sci.112, 97-106.

Moldenke, H.L. and Moldenke, A.L. (1981). Verbenaceae. pp 196-410 In: Dassanayake, M.D. and Fosberge, F.R. (Ed. ) Flora of Ceylon. Vol IV. Amerind Publishing Co.(Pvt.).New Dehli, India.

Mohan, M.L. and Krishnamurthy, K.V. (2002). Somatic embryogenesis and plant regeneration in pigeon pea. Biol. Plant. 45, 19-25.

Murashige, T. and Skoog, F. (1962). A revised medium for rapid growth and bioassays with tobacco tissue cultures. Physiol. Plant. 15, 473-497.

Murthy, B.N.S., Murch, S.J. and Saxena, P.K. (1995). Thidiazuron induced somatic embryogenesis in intact seedlings of peanut (Arachis hypogaea L.): endogenous growth regulator levels and significance of cotyledons. Physiol. Plant. 94, 268-276.

Samarasekara, S. (1995). Information analysis agro-products. Floriculture products. Trade information series, Sri Lanka export development board, Colombo.

Taylor, N.J. and Fauquet, C. M. (2002). Microparticle bombardment as a tool in plant science and agricultural biotechnology. DNA Cell Biol. 21, 963-977.

Thomas, T.D. (2003). Thidiazuron induced multiple shoot induction and plant regeneration from Cotyledonary explants of Mulberry. Biol. Plant. 46, 529-533. 
Victor, J.M.R, Murch, S.J., Krishnaraj, S. and Saxena, P. K. (1991). Somatic embryogenesis and organogenesis in peanut: The role of Thidiazuron and N6-benzylaminopurine in the induction of plant morphogenesis. Plant Growth Regul. 28, 9-15.

Yasmin S, Nasiruddin K.M., Begum, R. and Talukder, S.K. (2003). Regeneration and establishment of potato plantlets through callus formation with BAP and N.A.A. Asian J. Plant Sci. 2(12), 936-940. 